\title{
7. The Royal Papua New Guinea Constabulary
}

\section{ABBY MCLEOD AND MARTHA MACINTYRE}

In Papua New Guinea, the police, being members of the Royal Papua New Guinea Constabulary (RPNGC), feature heavily in popular discussions of law, order and HIV. Most typically, the police are perceived as adversely impacting upon the epidemic, via the entrenchment of negative attitudes to prostitution, police brutality and the rape of victims and offenders in communities and police stations. In addition to these harmful impacts, the RPNGC has been actively involved in HIV prevention, both within the constabulary and the community at large. This chapter discusses the ways in which the RPNGC has, and continues to, impact both negatively and positively upon the course and management of HIV and AIDS in Papua New Guinea. The views presented in this paper emanate largely from the authors' experiences as gender advisers to the RPNGC during Phase III (2000-5) of the Royal Papua New Guinea Constabulary Development Project (AusAID/GoPNG). ${ }^{1}$

\section{Perpetuating HIV and AIDS: Police Action and Inaction}

In Papua New Guinea, as in many other countries, the police are implicated in the spread of HIV (see Luker and Dinnen this volume). Police actions such as rape and brutality directly contribute to the transmission of the virus, while police inaction in cases of rape and domestic violence allows such crimes to continue unchecked. As outlined below, police attitudes to violence and masculinity play a significant role in the ongoing occurrence of 'risk behaviours'.

\footnotetext{
1 The RPNGC Development Project was a 15 year institutional strengthening and capacity building project, which commenced in 1989 and ended in February 2005. The project was conducted in three distinct phases. Phase I, which was managed by Price Waterhouse Coopers, focussed upon organisational development. Phases II and III were managed by ACIL, with Phase II emphasizing operations support and training and Phase III concentrating on overall capacity building. Both police and civilian advisers were employed, with gender advisers responsible for promoting improved treatment of women employees and users of the constabulary being employed in all three phases.
} 
Civic Insecurity

\section{Police Attitudes}

Workshops held by both gender advisers, aimed at garnering (and challenging) police members' views about domestic and sexual violence demonstrate that the views of police differ little from those of many community members, despite their role as enforcers of laws that render domestic and sexual violence criminal offences. While police officers, by and large, are familiar with and understand the laws that they are paid to enforce (although some confusion has resulted from recent amendments to sexual offences legislation (see Stewart this volume)), the moral views of those officers are contrary to the morals embraced by these laws, which emanate from the Queensland Criminal Code as it has been adopted and applied in Papua New Guinea (cf. Fletcher and Gonapa this volume). For example, rape within marriage is entirely acceptable to many police, as women for whom bride-price has been exchanged are viewed as being required to 'give sex' to their husbands whenever it is demanded (see Eves this volume, Hammar this volume). Similarly, despite the fact that domestic violence constitutes assault under the Criminal Code, like rape in marriage, the vast majority of police officers deem violence within marriage to be perfectly reasonable.

Like many other Papua New Guineans, police share attitudes towards the use of violence as a way of 'resolving' disputes or solving problems that are often at odds with Western liberal values enshrined in law. Thus in a meeting with policewomen where the subject of training in 'mediation' and 'dispute resolution' was being discussed, the majority of women present endorsed the idea that a woman had the right to physically assault another woman who was having an affair with her husband. While some believed that it should still be considered criminal assault, most were of the view that it should be treated with leniency - effectively in a similar fashion to a murder that is crime passionel under French law. The women who participated in the discussion justified their use of violence (several indicated that they had physically attacked other women whom they thought were 'breaking up' their marriages) as both 'natural' and in terms of Papua New Guinea 'custom'. They were convinced that in administering a beating they were simultaneously venting their anger, ensuring that the woman would not continue her adulterous affair, and enacting a justifiable punishment (McLeod 2007, 80).

Similarly, in consultations on community policing strategies in villages and urban settlements, while many people complained about police brutality, on several occasions people emphasised the fact that they objected to unjust beatings of adolescent boys whom the police had designated raskols. They were not critical of all police violence and spoke approvingly of incidents where police had assaulted young men who were widely believed (or known) to be violent criminals. During focus groups conducted in the Highlands region in 
2004, several community groups claimed that they respected the police more when they employed violence and displayed their guns. ${ }^{2}$ The humiliation of prostitutes by police or the public use of violence in apprehending robbers in the 'Millennium Robbery' affront Western liberal sensibilities and ideals of justice (see Fletcher and Gonapa this volume, Jenkins this volume). ${ }^{3}$ But for the many onlookers who jeered and cheered, these actions by the police were approved forms of 'justice'.

'Panel beating' is an anticipated and generally acceptable feature of police interactions with the community, occurring both publicly and within the confines of police holding cells (HRW 2005; 2006). Suspects are frequently beaten with fists, batons and firearms, in addition to being kicked and thrown. Not unexpectedly, police beatings often cause serious injuries, resulting in exposure to large amounts of blood. Given the prevalence of skin conditions such as ulcers, and the likelihood of violent police officers receiving wounds from retaliating suspects, police brutality poses genuine risks for the transmission of HIV and other blood-borne infections.

\section{Police as Perpetrators of Rape}

A survey of community attitudes to the police, conducted by the RPNGC Development Project, found that 50 percent of respondents (both men and women) were afraid of the police (RPNGC 2004; cf. PNG JAG 2008, 96-98). When discussing this fear with individual women and women in focus groups, they claimed that they were afraid of reporting crimes to the police, lest they become re-victimised. Many women relayed experiences of being told that their complaints would be investigated in exchange for sex, but not otherwise, and there is a widespread perception that policemen are often responsible for the rape of women on police premises (cf. Jenkins this volume). As such crimes are rarely reported (primarily due to fear of retaliation), it is difficult to ascertain the prevalence of rape by police. However, entries in the sexual assault registers of several stations throughout the country prove the existence of such behaviour (which rarely results in internal disciplinary or legal action), the incidence of which has been highlighted in widely publicised reports by Human Rights Watch (HRW 2005; 2006).

2 'Respect' for someone is often understood as involving 'fear' of that person's aggression and prowess (Macintyre 2008, 184)

3 On 17 December 1999, five armed men hijacked a helicopter and landed it on the roof of the PNG Banking Corporation in attempt to commit a robbery. The robbery failed when the police shot down the departing helicopter. All five suspects later died of bullet wounds, which the coroner attributed to police gunfire. 
The issue of internal investigation and discipline was addressed in each phase of the AusAID police project. Training and advice has ensured that there is a high level of awareness about procedures and the standard of internal investigation is often high. But this does not mean that appropriate action proceeds from the findings of an investigation. Various forms of avoidance, incompetence and nepotism intervene and ensure that some people are not brought to justice. The impunity that prevails means that policewomen too are in some instances fearful of their male colleagues, resulting in requests by particular policewomen not to be rostered on shifts without other women, for fear of being raped or sexually assaulted by their colleagues. Policewomen have also expressed concern about situations in which men and women are simultaneously placed in police holding cells, as they claim that policemen turn a blind eye to the rape of female detainees by male detainees and that they themselves are too scared to intervene.

These ideas about female sexual 'availability', male entitlement and the use of rape as a form of punishment for female 'immorality' are not unique to police (see Eves this volume; Hammar this volume; Luker and Monsell-Davis this volume). In 2002, in community meetings about ways of reducing crime, people regularly suggested that women, especially young women, should not be permitted to walk about after dark; should be required to dress in ways that did not invite male attention; and on several occasions suggested that rape victims who had in any way transgressed had in fact invited the assault.

\section{The RPNGC: Masculinity and Violence}

The constabulary comprises approximately 5,200 sworn members, of whom only 5.4 percent are women. Consequently, the constabulary is an extremely masculine organisation. As previously mentioned, police violence is widely accepted and in some areas respected, rendering it an important part of police, particularly male, identity. So too, many policemen perceive themselves as powerful, by virtue of their profession (and access to guns) - a power that they seek to reinforce over women by rape and sexual harassment. While most police are aware that such actions contravene human rights, criminal law and the police code of ethics, they simultaneously enjoy the power conferred upon them as a result of their position, which is particularly attractive in a contemporary society in which there is deemed to be a 'crisis of masculinity'.

The resort to violence by men generally is not judged as a failure of self-control, but as an assertion of masculine authority. As such, whether the violence is in the home, on the streets of Port Moresby, or in the course of police duties, men who are able to successfully, if illegally, dominate others by force are in some respects admired. On both sides of the law, the image of 'Rambo' is positive (Macintyre 
2008). Members of the mobile squads, police serving in Bougainville (as well as their opponents), 'tribal' warriors in the Highlands and adolescent boys swaggering around Lae or Port Moresby don headbands, shades and militaristic clothing and are enthusiastic consumers of videos that valorise muscular rough justice and the triumph of the hero who operates 'outside the law'.

Within the police force acts of violence are also justified in terms of 'frustration'. Many police think that the justice system favours criminals and thwarts their efforts at combating crime. Their efforts at pursuing and charging offenders are thus fruitless - and they feel diminished by the failures of prosecution. Violence and aggression are in many ways assertions of masculine potency. Defiance or 'lack of respect' from members of the public provoke responses by policemen that seem disproportionately brutal and are readily interpreted as indicative of fragile masculine egos - but such psychologising is of little comfort to a person who has been injured.

Working within the RPNGC enabled us to see at first hand the ways that frustration over working and living conditions sapped morale (cf. Pantumari and Bamne this volume). Once, after a discussion of the international human rights of those in custody (using images of clean police cells with electric lights, a bunk to sleep on and a toilet) one young policeman observed, 'If we had cells like that at the station, I'd move the prisoners into the barracks and live there myself!' The single men's barracks in which he lived had been condemned by health authorities, there was no married housing available and his wife and children lived in a squatter settlement. Wages are low; facilities often inadequate and there are often budget shortfalls that mean cars cannot be serviced or fuelled; phones do not work and fax machines or photocopiers cannot be maintained. Police resentment of Australian advisers often derives from their belief that the funds allotted to projects aimed at expanding training or 'capacity-building' would be better spent on infrastructure and maintenance so that they could perform their duties efficiently.

Arrogant and aggressive acts are thus often 'compensatory'. Policemen are able to wield power and authority in the communities where they work and they undoubtedly do so in a variety of ways - some petty, not all of them in areas that are related to their jobs. In some respects the abuses of power are a way of maintaining status and power in the context of low morale. Police in PNG (as elsewhere) can enjoy free meals, drinks and small 'perks' from members of the public who offer them in return for good relations or favours. Seizure of goods such as betel nut or cigarettes from unlicensed street vendors is sometimes conceptualised thus, especially if the vendors are not charged. Sex, is similarly perceived as a 'perk' of the job for some policemen (see Jenkins this volume). 
By virtue of their profession, police will always be a mobile part of the community - literally in the case of members of the mobile squad. Their mobility in remote rural areas provides a form of social invisibility and disconnectedness, as there they are not recognisable members of a community, in the way that police working at a station are. Their actions in rural areas also escape media attention, as the media is concentrated in urban centres and people do not have ready access to complaint mechanisms, so that often breaches of discipline, administration of harsh 'rough justice' and even criminal offences go unrecorded. But stories abound and are sometimes elaborated in ways that ensure that the reputation of police as violent and unjust dominates the public image that circulates in both rural and urban environments. In areas of the Highlands provinces where tribal fighting has occurred sporadically (and sometimes continuously) for many years, the mobile squads are notorious for their acts of violence and punitive retribution against people and property. In some instances villagers have sued for reparation and won, at heavy cost to the government. Such cases are then publicised so that police notoriety is reinforced nationally.

\section{Preventing HIV: RPNGC Initiatives}

While members of the Royal Papua New Guinea Constabulary are most commonly associated with the transmission of HIV (through the aforementioned practices), the constabulary has simultaneously attempted to contribute to HIV prevention, both among its own staff and in the community. With the assistance of the Royal Papua New Guinea Constabulary Development Project (1989-2005), a number of initiatives were introduced, with a particular focus upon basic awarenessraising (see Patrick this volume).

According to O'Collins (2005), a previous gender adviser on the RPNGC Development Project, the constabulary began addressing HIV and AIDS in 1990, against a backdrop of rising concern about the epidemic and workshops such as the Health Department's 'HIV/AIDS and the Work Place' meeting (30 November 1990). At that time, constabulary members had reportedly begun dying of HIV-related illnesses and there was much misunderstanding about the disease, including its modes of transmission. Given cultural constraints upon the open discussion of sexual matters and the stigma attached to HIV and AIDS, early attempts to address HIV/AIDS within the constabulary were met with resistance and were hence undertaken as subtly as possible, being subsumed among the general activities of the RPNGC Welfare Unit.

In 1991, a policy entitled AIDS in the Workplace: Policy Directives for the RPNGC, based upon a Papua New Guinea Defence Force (PNGDF) policy directive, was released as Commissioner's Circular 13/91(see Pantumari and Bamne this volume). 
Designed to equip members of the RPNGC with knowledge about the virus, its effects and prevention, the policy outlines training directives, precautionary measures, procedures for the supervision of HIV positive members, virus detection and screening measures and processes for maintaining confidentiality and respect. Throughout the 1990s, attempts were made to address HIV in most training courses and HIV considerations were incorporated into cell and custody procedures.

In Phase III of the RPNGC Development Project (2000-5), constabulary trainers, in collaboration with the project's training adviser developed a training package for use within the constabulary in order to educate constabulary members about the transmission and prevention of HIV. This package, which has also been used in police barracks, has been delivered to RPNGC members throughout the country, as have training packages on gender and human rights. In addition, an HIV/AIDS module was prepared for the competency acquisition program, which is a self-directed learning program for probationary constables. Posters aimed at raising awareness of HIV transmission and prevention are displayed in most police stations. While discussions suggest that they have aided awareness, their impact on actual behaviour remains unknown. In addition to training for members of the RPNGC and their families, the Community Policing division of the RPNGC actively participates in HIV awareness training in the community, using materials developed both internally and by the National AIDS Council. Training assumes a number of forms, including ad hoc verbal awareness raising at market places, seminar-style training for community groups, school visits and police-hosted theatre group presentations. Community police officers also distribute pamphlets on HIV and both male and female condoms to community groups. In addition to raising awareness of HIV specifically, the community police make reference to HIV when conducting training on both domestic and sexual violence. The constabulary is well networked with the National AIDS Council, the Provincial AIDS Councils and NGOs working on related issues, including the Family and Sexual Violence Action Committee.

As noted by Jenkins (this volume), members of the constabulary have previously participated in action research programs and more recently in a similar program with the European Union, which involves the training of peer educators. While there have been previous attempts to ensure that police officers working in high risk operations have been provided with plastic gloves, the provision of gloves is sporadic. This aspect of HIV prevention, namely occupational precautions, has been less substantially addressed than awareness-raising.

The constabulary has produced Workplace Policy on HIV/AIDS to supersede Circular No. 13/91. The policy, drafted in keeping with the HIV/AIDS Management and Prevention (HAMP) Act 2003 (see Stewart this volume), contains basic information about HIV and AIDS and condemns discrimination 
against HIV-positive people, including attempts to deny HIV-positive members access to training, promotions, housing or other entitlements. As per circular 13/91, the policy requires that applicants be screened for HIV as part of the standard recruitment medical test and disqualified from further consideration in the event that they test HIV positive (cf. Pantumari and Bamne this volume). The policy places responsibility for the dissemination of relevant information in the hands of the welfare and training officers and reinforces the need for confidentiality and privacy of information pertaining to members' HIV status. Despite much resistance to the idea, the policy states that 'the constabulary should ... provide or facilitate access to condoms for its officers, which can be obtained by personal choice', and that hand gloves should be supplied for members attending to incidents involving injuries and bleeding.

In addition to the constabulary's agency specific HIV/AIDS policy, attempts to address HIV at the sectoral level are being made by all law and justice sector agencies, in collaboration with the Law and Justice Sector Program (LJSP) (see Patrick this volume), aimed at supporting the development of sector-wide knowledge and involvement in the prevention and management of HIV and AIDS.

\section{Police Attitudes to HIV}

While there is little doubt that awareness-raising activities within the constabulary have contributed to gains in members' knowledge about the transmission and prevention of HIV, as no systematic research has accompanied the implementation of training programs, it is impossible to ascertain changes to attitudes and behaviours. Casual conversations and workshop discussions with police officers suggest that there is now general understanding of the ways in which HIV is transmitted and prevented, and of the need for nondiscriminatory treatment of HIV positive people. There is however, an ongoing reluctance by police officers (particularly women) to carry condoms, lest their partners accuse them of being promiscuous. Policewomen, many of whom are married to policemen, express the desire to control their own sexual health by asking their husbands (whom they know to have multiple sexual partners) to use condoms. Simultaneously, however, they struggle with the violent implications of such requests and hence feel powerless to control their own bodies (cf. Eves this volume). This was aptly demonstrated by a policewoman, who, during an HIV workshop discussion of female condoms asked, 'How long can you leave these condoms in for? My husband comes home drunk early every morning and rapes me. Maybe I could put it in before I go to bed?' 
Unfortunately, the change in attitudes to prostitutes documented by Jenkins (this volume), following work with the police in 1996, do not appear to have been sustained-few policemen and policewomen are sympathetic to prostitutes, and policewomen appear no more lenient in their views than their male colleagues. The HIV/AIDS awareness comic book produced in the context of the project discussed by Jenkins was used in workshops conducted in 2002. It was interpreted by some police participants as giving information about ways that HIV could be contracted in the context of their work; but equally was considered to be an official endorsement of the 'rights' of police to take known prostitutes into their barracks and require that they have sex with multiple partners. Many police officers, both men and women, do not accept that a prostitute can be raped, a view which is perpetuated by the belief that prostitutes attempt to lay charges for rape only when their customers have failed to pay for services rendered. In 2004, the public humiliation by police of prostitutes working in the Three-Mile Guesthouse serves to further emphasise their attitudes to the profession (see Fletcher and Gonapa this volume; Stewart this volume).

The images of modern masculinity in Papua New Guinea still entail gender distinctions that render liberal humanistic notions of the communication between men and women-especially over sexual matters-alien. Companionship between men and women is not an ideal embraced by many people, much less 'naturalised' as providing the basis for negotiating aspects of a personal relationship (cf. Pantumari and Bamne this volume; Wardlow 2009). In workshops on domestic violence, policewomen and the wives of policemen commented that it was difficult to discuss birth control, sexual needs and even domestic issues where there were differences of opinion. Often the living conditions prevailed against intimate conversation and notions of 'shame' (which encompasses 'shyness' in common usage) inhibited women. Asking a husband to use a condom was tantamount to accusing him of being adulterous, or admitting that one had engaged in extramarital sex and so might have contracted an infection. Either way, women who spoke of the problems facing them believed that condom usage in marriage was an unrealistic expectation, inviting violence from an affronted husband (see Eves this volume). Human rights approaches to HIV prevention require acceptance of notions of gender equity and that cannot be assumed.

In some communities people have neglected, rejected and even murdered people suspected of having AIDS. Links are made between witchcraft and HIV that have further stigmatised people with the infection (see Luker and Dinnen this volume, ch. 1; Haley this volume). The posters that were meant to ensure that the public recognised that people with HIV could look like any normal person and therefore accept sufferers as members of their community, in some ways 
reinforce the link. For just as witches can appear to be 'normal' while inflicting harm on those around them, so the person who transmits HIV to another can do so to 'innocent victims'. ${ }^{4}$ The emphasis on patient confidentiality and its enshrinement in law strengthens both the existing association of secrecy, immorality and the wilful infliction of harm and the view that there are 'guilty' and 'innocent' people who contract the disease. Given the double standards in sexual morality that prevail, women who are considered sexually promiscuous are considered doubly guilty. They invite illicit sex and threaten the health of others - and so should be exposed and punished as anti-social and dangerous.

In discussions of human rights with police in 2002, several expressed the view that publicly exposing people with HIV or AIDS was a 'customary' way of making people safe and would 'deter' men from consorting with them. They were in effect reluctant to extend 'human rights' to those whom they considered immoral and socially irresponsible. Others were more accepting of the need to promote acceptance and support for people with AIDS - their position was expressed in terms of Christian ideals of charity and mercy. But such views often involved harsh moral judgements and the more evangelical were also more inclined to believe that 'repentance' and faith could cure the illness (see Hammar this volume; Wardlow 2008; Eves 2003). The emphasis on monogamous fidelity as the best means of preventing transmission effectively endorses the view that it is a disease of the immoral. These responses are not unique to members of the police force and reflect a climate of opinion and a dogmatic moralism that need to be acknowledged.

\section{Conclusions}

For almost two decades the RPNGC has been exposed to education and awareness programs aimed at improving understanding and compliance with basic human rights. By 2000 all members of the force were 'aware' of human rights issues. Aid programs implemented by AusAID, the European Union and the Red Cross have continued to emphasise the human rights of citizens and the international standards that must be maintained in a just society. More recently, senior police, including the police commissioner, have taken a leading role in advocating against gender violence. Measures introduced within the force include an equal opportunity policy, the promotion of female officers to senior positions, the establishment of a Victims Crimes Desk and changing the name of the Sexual Offences Squad to the Family and Sexual Violence Squad (Mabone 2009).

4 For a discussion of other unintended readings of AIDS posters, see Macpherson 2008, 233-240). 
But such measures do not swiftly translate into actions at large that defend or uphold the rights of citizens. Indeed, in one session dealing with gender, several policemen who had demonstrated a thorough understanding of the principles underpinning policies on equality of opportunity insisted that 'such things cannot be accepted for perhaps twenty years in Papua New Guinea'. They were not hostile to the principles, they simply regarded them as unrealistic and unattainable. They were phlegmatic rather than pessimistic - attitudes that must be understood in the context of their own conditions of employment as much as the environment in which they work (McLeod 2007, 80-81).

Our analysis of the ways in which the Royal Papua New Guinea Constabulary impacts upon the course and management of HIV and AIDS in Papua New Guinea demonstrates the myriad ways in which a single organisation can be involved in both the transmission and prevention of the virus. Our aim has been to shed light upon the difficulties involved in tackling the epidemic in Papua New Guinea via Western analytical frames, such as human rights (see Reid this volume). In emphasising the multiple layers of cultural identity-both societal and organisational - that hamper the success of initiatives aimed at curbing police involvement in the transmission of HIV, we draw attention to the ways that police are simultaneously part of the communities in which they operate. Ultimately, however, the analysis points to the urgent need to bridge the gap between awareness and behavioural change, a challenge that is by no means unique to the constabulary.

\section{References}

Eves, Richard. 2003. AIDS and Apocalypticism: Interpretations of the Epidemic from Papua New Guinea. Culture, Health and Sexuality 5 (2): 249-264.

HRW (Human Rights Watch). 2005. 'Making Their Own Rules': Police Beatings, Rape and Torture of Children in Papua New Guinea. http://www.hrw.org/en/ node/11626/section/1 (accessed 27 April 2010).

HRW (Human Rights Watch). 2006. Still Making Their Own Rules: Ongoing Impunity for Police Bearings, Rape and Torture in Papua New Guinea. New York: Human Rights Watch.

Mabone, Travertz. 2009. Baki: I'll End Violence against our Women. The National, 25 March 2009.

Macintyre, Martha. 2008. Police and Thieves, Gunmen and Drunks: Problems with Men and Problems with Society in Papua New Guinea. The Australian Journal of Anthropology 19 (2): 179-193. 
MacPherson, Naomi. 2008. 'SikAIDS: Deconstructing the Awareness Campaign in Rural West New Britain, Papua New Guinea. In Making Sense of AIDS: Culture, Sexuality, and Power in Melanesia, ed. Leslie Butt and Richard Eves, 224-245. Honolulu: University of Hawai'i Press.

McLeod, Abby. 2007. Police Reform in Papua New Guinea. In Security in the Pacific Islands: Social Resilience in Emerging States, ed. M. Anne Brown, 7388. London and Boulder: Lynne Rienner Publishers.

O'Collins, M. 2005, Personal Communication, September 2005.

PNG (Papua New Guinea) JAG (Justice Advisory Group). 2008. Urban Crime Victimisation in Papua New Guinea 2004-2008: A Synthesis.

RPNGC (Royal Papua New Guinea Constabulary). 1991. AIDS in the Workplace: Policy directives for the RPNGC, Commissioner's Circular 13/91.

RPNGC (Royal Papua New Guinea Constabulary). 2004. Report on Community Perceptions of the Police in Papua New Guinea. Unpublished project document. Port Moresby: Development Project, Phase III.

Wardlow, Holly. 2009. 'She Liked It Best When She Was on Top': Intimacies and Estrangements in Huli Men's Marital and Extra Marital Relationships. In Intimacies: Love and Sex Across Cultures, ed. William R. Jankowiak, 174194. New York: Columbia University Press.

Wardlow, Holly. 2008. 'You have to Understand: Some of Us are Glad AIDS has Arrived': Christianity and Condoms among the Huli, Papua New Guinea. In Making Sense of AIDS: Culture, Sexuality, and Power in Melanesia, ed. Leslie Butt and Richard Eves, 187-205. Honolulu: University of Hawai'i Press. 